\title{
HEMODYNAMIC STUDIES ON HYPERTENSION** (PART II) EFFECTS OF ISOPROTERENOL, PROPRANOLOL, NORADRENALINE AND PHENTOLAMINE

\author{
ON THE HEMODYNAMICS IN ESSENTIAL HYPERTENSION
}

\author{
MASAYUKI TSUCHIYA *
}

$I^{\mathrm{N}}$ 1906, Dale 1 found that preparations of ergot not only abolished the pressor action of adrenaline but also reversed it, producing a depressor effect. Fourty two years later Ahlquist $^{2}$ extended Dale's observations by showing that the action of various sympathomimetic amines on cardiovascular system and other tissues was different. He postulated two types of adrenergic receptors, which he named alpha and beta adrenergic receptor. Activation of beta receptors causes myocardial stimulation and vasodilatation while activation of alpha receptors produces vasoconstriction. On the other hand, it has been uniformly accepted that the increase in peripheral resistance is responsible for the pathogenesis of high blood pressure. Although an increased secretion of catecholamines has not been convincingly demonstrated as an etiological mechanism of the disease, it is conceivable that an increased vascular reactivity could result in increased peripheral resistance and hypertension. In fact there have been many papers on the vascular reactivity to noradrenaline in hypertension, often with contradictory results. However, as demonstrated in the previous report ${ }^{3}$ peripheral resistance is not the sole determinant of pressure and there exists

$\begin{array}{cl}\text { Key Words: } & \text { Essential Hyperten sion } \\ & \text { Hemodynamics } \\ & \text { Isoproterenol } \\ & \text { Propranolol } \\ \text { Noradrenaline } \\ \text { Phentolamine }\end{array}$

varying hemodynamic patterns in essential hypertension: high cardiac output with normal or low peripheral resistance can be observed in some of hypertensive patients. Frohlich et al. ${ }^{4-6}$ argued that an increased sensitivity of beta receptors can be found in subjects with hyperdynamic beta adrenergic circulatory state, some of them exhibiting blood pressure elevation. They also suggested the possibillity that a beta adrenergic mechanism may be playing important roles in the labile hypertension as well as in the hyperdynamic beta adrenergic circulatory state. ${ }^{7}$ The purpose of this study was to determine whether or not any abnormality in the responsiveness of alpha or beta adrenergic receptor exists in hypertension. Isoproterenol stimulates exclusively beta receptors, whereas the action of noradrenaline is almost exclusively on alpha receptors? Propranolol selectively blocks beta receptors 8 and phentolamine blocks only alpha receptors. Accordingly, the experiment was designed to compare the hemodynamic responses to the intravenous infusion of these agonists and antagonists for each adrenergic receptor between normotensive subjects and hypertensive patients.

\section{Materials and Methods}

All of the materials were selected from a large group of normotensive subjects and hypertensive patients, whose resting supine hemodynamic studies were previously reported 3 These individuals underwent some of the following studies on

(Received for publication, September 28, 1971)

* The 2nd Department of Internal Medicine, School of Medicine, Kanazawa University, Kanazawa, Japan. (Director: Prof. M. Murakami)

** The outline of this study was reported at the Symposium of the joint meeting of the 30th Tokai and 8th Hokuriku Regional Meeting of the Japanese Circulation Society, Nagoya, November 7, 1970. 
TABLE I PHYSICAL CHARACTERISTICS OF NORMOTENSIVE AND HYPERTENSIVE GROUPS IN EACH STUDY

\begin{tabular}{|c|c|c|c|c|c|c|c|c|c|}
\hline \multirow{2}{*}{$\frac{\text { Infusion }}{\text { Group }}$} & & \multicolumn{2}{|c|}{ Isoproterenol } & \multicolumn{2}{|c|}{ Propranolol } & \multicolumn{2}{|c|}{ Noradrenaline } & \multicolumn{2}{|c|}{ Phentolamine } \\
\hline & & $N T$ & $H T$ & $N T$ & $H T$ & $N T$ & $H T$ & $N T$ & $H T$ \\
\hline Number & & 14 & 14 & 15 & 15 & 11 & 13 & 12 & 17 \\
\hline \multirow{2}{*}{ Age (years) } & (Mean) & 43.1 & 42.1 & 43.1 & 45.2 & 43.0 & 45.1 & 41.9 & 44.6 \\
\hline & (Range) & $30-59$ & $30-59$ & $31-59$ & $32-58$ & $33-59$ & $30-58$ & $30-59$ & $30-58$ \\
\hline \multicolumn{2}{|c|}{ Sex (male : female) } & $8: 6$ & $10: 4$ & $9: 6$ & $11: 4$ & $7: 4$ & $11: 2$ & $8: 4$ & $14: 3$ \\
\hline \multicolumn{2}{|c|}{$B S A\left(m^{2}\right)$ (Mean) } & 1.59 & 1.52 & 1.58 & 1.57 & 1.55 & 1.62 & 1.58 & 1.63 \\
\hline
\end{tabular}

Abbreviations: $N T=$ normotensive subjects; $\quad H T=$ hypertensive patients; $\quad B S A=$ body surface area

different days.

Isoproterenol Infusion: Fourteen normotensive subjects and 14 hypertensive patients were studied. Hemodynamic measurements were obtained before and $5 \mathrm{~min}$ after commencing intravenous infusion of isoproterenol at $2 \mu \mathrm{g} / \mathrm{min}$.

Propranolol Infusion: Fifteen normotensive subjects and 15 hypertensive patients were studied. Hemodynamic measurements were obtained before and $2 \mathrm{~min}$ after the end of the intravenous injection of propranolol, $5 \mathrm{mg}$, over $5 \mathrm{~min}$ period.

Noradrenaline Infusion: Eleven normotensive subjects and 13 hypertensive patients were studied. Hemodynamic measurements were obtained before and $5 \mathrm{~min}$ after commencing intravenous infusion of noradrenaline at $15 \mu \mathrm{g} / \mathrm{min}$.

Phentolamine Infusion: Twelve normotensive subjects and 17 hypertensive patients were studied. Hemodynamic measurements were obtained before and $5 \mathrm{~min}$ after commencing intravenous infusion of phentolamine at $2 \mathrm{mg} / \mathrm{min}$.

All hypertensive patients were diagnosed as having essential hypertension based on routine clinical studies. Mean blood pressure for normotensive group. was below $110 \mathrm{mmHg}$, whereas that for hypertensive group was above 110 $\mathrm{mmHg}$. These individuals who had a clinical evidence of cardiac decompensation, hypertensive encephalopathy or secondary hypertension, or a history of renal disease, previous myocardial infarction or cerebrovascular accident were eliminated from this series. All patients studied had no treatment, or it had been discontinued for at least two weeks before performing the hemodynamic study.

The hypertensive patients in each study were selected from a large group on the basis of matching their ages with those of the normotensive subjects. As indicated in Table I, there is no difference in age between normotensive subjects and hypertensive patients in any study. Measurements of cardiac output, heart rate and blood pressure, and calculations of hemodynamic parameters were fully described in the previous report? After control data were obtained in the resting supine position, each hemodynamic study was carried out by the method described above.

\section{RESULTS}

The hemodynamic data are summarized in Table II, IV, VI and VIII. Fig.1 to 4 show individual hemodynamic alterations induced by intravenous infusion of the four drugs. The difference in the hemodynamic responses to each drug between normotensive and hypertensive groups is presented in Table III, V, VII and IX. Response to Isoproterenol Infusion ( Table II to III, Fig .1).

The constant intravenous infusion of isoproterenol at a rate of $2 \mu \mathrm{g} / \mathrm{min}$ produced nearly similar hemodynamic changes in both groups. The mean systolic pressure rose in both groups, but this change was significant only for normotensive group, in which the average systolic pressure rose from 125 to $146 \mathrm{mmHg}(\mathrm{p}<0.001)$. In 4 patients with hypertension there was a reduction in systolic pressure due to a marked reduc- 
TABLE II THE EFFECT OF THE ADMINISTRATION OF ISOPROTERENOL ON THE HEMODYNAMICS IN NORMOTENSIVE SUBJECTS AND HYPERTENSIVE PATIENTS

\begin{tabular}{|c|c|c|c|c|c|c|}
\hline & \multicolumn{3}{|c|}{ Normotensive subjects } & \multicolumn{3}{|c|}{ Hypertensive patients } \\
\hline & Before & After & $P<$ & Before & After & $P<$ \\
\hline$S B P(m m H g)$ & $125 \pm 9.6$ & $146 \pm 12.7$ & 0.001 & $168 \pm 11.4$ & $176 \pm 12.4$ & $n s$ \\
\hline$D B P\left(m m H_{g}\right)$ & $81 \pm 6.3$ & $67 \pm 7.1$ & 0.001 & $100 \pm 7.5$ & $83 \pm 13.9$ & 0.001 \\
\hline$M B P(m m H g)$ & $96 \pm 6.2$ & $93 \pm 6.4$ & $n s$ & $123 \pm 7.7$ & $114 \pm 10.6$ & 0.001 \\
\hline$C I\left(L / \mathrm{min} / \mathrm{m}^{2}\right)$ & $3.95 \pm 2.141$ & $7.68 \pm 3.439$ & 0.001 & $3.30 \pm 1.305$ & $6.01 \pm 2.590$ & 0.001 \\
\hline$H R$ (beats $/ \mathrm{min}$ ) & $70 \pm 9.6$ & $111 \pm 16.9$ & 0.001 & $67 \pm 13.4$ & $108 \pm 15.3$ & 0.001 \\
\hline$S I\left(\mathrm{ml} /\right.$ beat $\left./ \mathrm{m}^{2}\right)$ & $55 \pm 25.4$ & $71 \pm 36.1$ & 0.05 & $50 \pm 19.1$ & $55 \pm 20.6$ & $n s$ \\
\hline$T P R I\left(\right.$ dyne.sec. $\left.\mathrm{cm}^{-5} \cdot \mathrm{m}^{2}\right)$ & $2316 \pm 856.8$ & $1177 \pm 528.4$ & 0.001 & $3432 \pm 1322.5$ & $1833 \pm 893.8$ & 0.001 \\
\hline$L V W I\left(\mathrm{~kg} \cdot \mathrm{m} / \mathrm{min} / \mathrm{m}^{2}\right)$ & $5.2 \pm 2.97$ & $9.7 \pm 4.25$ & 0.001 & $5.5 \pm 2.03$ & $9.2 \pm 3.92$ & 0.001 \\
\hline
\end{tabular}

The cardiac output was determined before and 5 min after intravenously isoproterenol infusion of $2 \mu \mathrm{g} / \mathrm{min}$ for $8 \mathrm{~min}$. The results represent the means \pm standard deviation of the mean.

Abbreviations: $S B P=$ systolic blood pressure; $D B P=$ diastolic blood pressure; $M B P=$ mean blood pressure; $C I=$ cardiac index $; H R=$ heart rate $; S I=$ stroke index $; \quad T P R I=$ total peripheral resistance index; $L V W I=$ left ventricular work index; $n s=$ not significant.

TABLE III THE DIFFERENCES BETWEEN THE EFFECTS OF ISOPROTERENOL ON THE HEMODYNAMICS IN NORMOTENSIVE SUBJECTS AND HYPERTENSIVE PATIENTS

\begin{tabular}{|c|c|c|c|}
\hline & Normotensive subjects & Hypertensive patients & $P<$ \\
\hline$\Delta S B P(m m H g)$ & +20 & +8 & 0.01 \\
\hline$\triangle D B P(m m H g)$ & -14 & -18 & $n s$ \\
\hline$\triangle M B P(m m H g)$ & -2 & -9 & 0.05 \\
\hline$\Delta C I\left(L / \mathrm{min} / \mathrm{m}^{2}\right)$ & +3.72 & +2.70 & $n s$ \\
\hline$\Delta H R$ (beats $/ \mathrm{min})$ & +40 & +41 & $n s$ \\
\hline$\Delta S I\left(m l / b e a t / m^{2}\right)$ & +16 & +5 & $n s$ \\
\hline$\Delta T P R I\left(\right.$ dyne.sec. $\left.\mathrm{cm}^{-5} \cdot \mathrm{m}^{2}\right)$ & -1140 & -1598 & $n s$ \\
\hline$\Delta L V W I\left(\mathrm{~kg} \cdot \mathrm{m} / \mathrm{min} / \mathrm{m}^{2}\right)$ & +4.5 & +3.7 & $n s$ \\
\hline
\end{tabular}

Abbreviations: $\Delta=$ mean difference between the values before and after the administration of isoproterenol. Other abbreviations as in Table II.

tion in total peripheral resistance. The rise in systolic pressure was therefore significantly greater in normotensive group than in hypertensive group $(\mathrm{p}<0.01)$. Although the diastolic pressure showed a significant fall from 81 to $67 \mathrm{mmHg}$ in normotensive group and from 100 to $83 \mathrm{mmHg}$ in hypertensive group ( $p<0.001$ and $p<0.001$ respectively), the difference in these falls between the two groups was not significant. Whereas in normotensive group the mean blood pres- sure showed no remarkable changes, in hypertensive group it showed a significant fall from 123 to $114 \mathrm{mmHg}(p<0.001)$. The fall in mean blood pressure was significantly greater in hypertensive group than in normotensive group $(\mathrm{p}<0.05)$. In both groups there were equally significant increases in cardiac index and heart rate $(p<0.001)$. The resting cardiac index increased from 3.95 to $7.68 \mathrm{~L} / \mathrm{min} / \mathrm{m}^{2}$ in normotensive group and from 3.30 to $6.01 \mathrm{~L} / \mathrm{min} / \mathrm{m}^{2}$ in hypertensive group. 

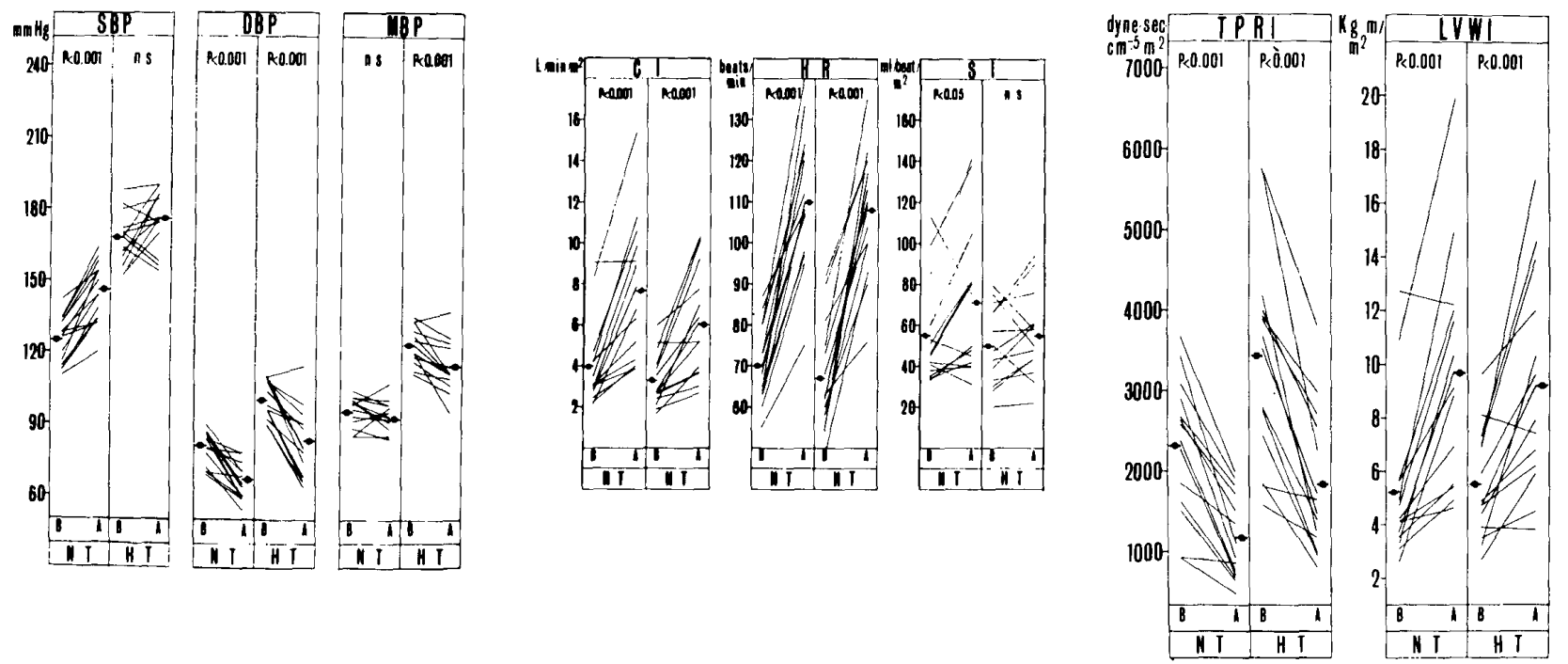

Fig.1. Effect of isoproterenol infusion on the hemodynamics in normotensive subjects (NT) and hypertensive patients (HT).

$\mathrm{B}=$ before and $\mathrm{A}=$ after isoproterenol. Other abbreviations as in Table II.

- mean value.

The heart rate increased from 70 to 111 beats/ min in normotensive group and from 67 to 108 beats/min in hypertensive group, there was a significant increase from 55 to $71 \mathrm{ml} / \mathrm{beat} / \mathrm{m}^{2}$ $(\mathrm{p}<0.05)$ in normotensive group. However, the difference in cardioacceleration between normotensive and hypertensive groups did not reach statistically significant levels. The average total

peripheral resistance index ( TPRI ) decreased from 2316 to 1177 dyne $\cdot \mathrm{sec} \cdot \mathrm{cm}^{-5} \cdot \mathrm{m}^{2}(\mathrm{p}<0.001)$ in normotensive group and from 3432 to 1833 dyne $\cdot \mathrm{sec} \cdot \mathrm{cm}^{-5} \cdot \mathrm{m}^{2}(\mathrm{p}<0.001)$ in hypertensive group, the difference being not significant. The average left ventricular work index ( LVWI ) increased by $4.5 \mathrm{Kg} \cdot \mathrm{m} / \mathrm{min} / \mathrm{m}^{2}(\mathrm{p}<0.001)$ in normotensive group and by $3.7 \mathrm{Kg} \cdot \mathrm{m} / \mathrm{min} / \mathrm{m}^{2}$
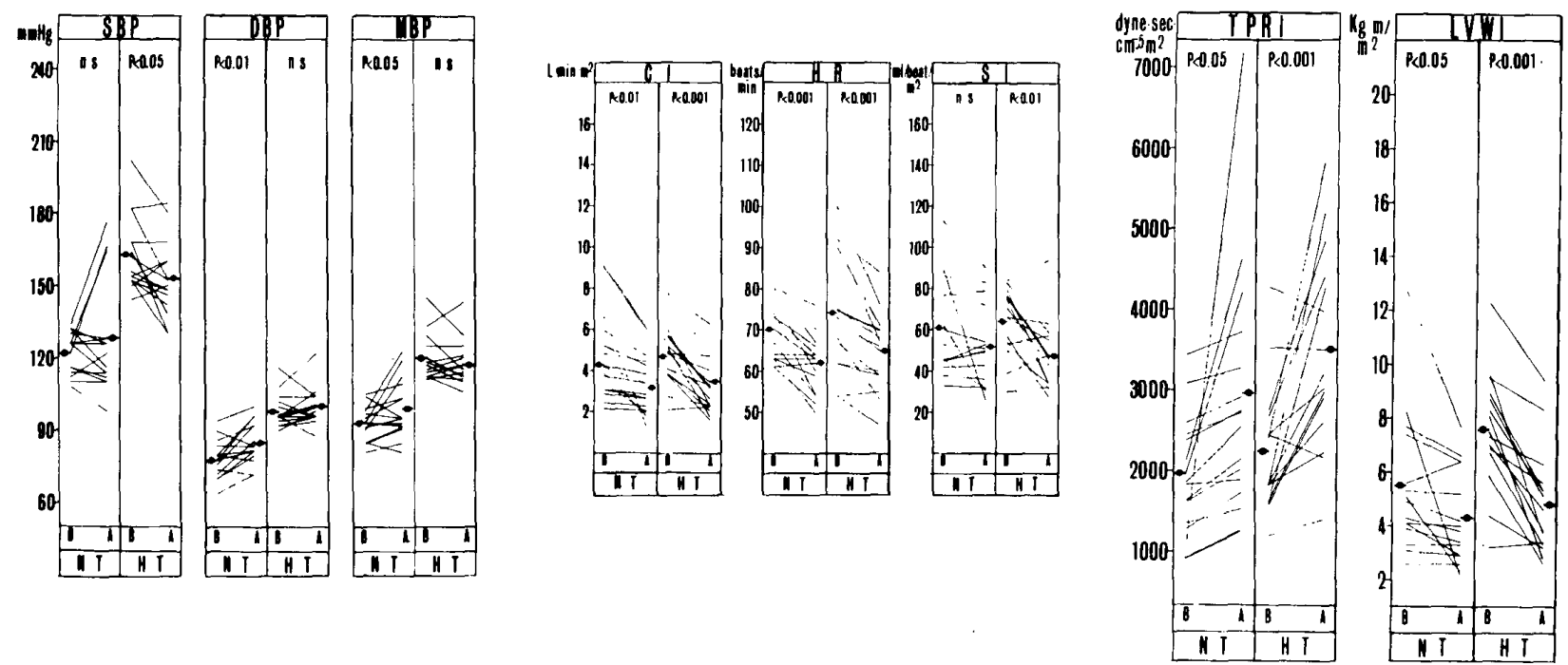

Fig. 2. Effect of propranolol infusion on the hemodynamics in normotensive subjects (NT) and hypertensive patients (HT).

$\mathrm{B}=$ before and $\mathrm{A}=$ after propranolol.

- = mean value.

Other abbreviations as in Table II. 
TABLE IV THE EFFECT OF THE ADMINISTRATION OF PROPRANOLOL ON THE HEMODYNAMICS IN NORMOTENSIVE SUBJECTS AND HYPERTENSIVE PATIENTS

\begin{tabular}{|c|c|c|c|c|c|c|}
\hline & \multicolumn{3}{|c|}{ Normotensive subjects } & \multicolumn{3}{|c|}{ Hypertensive patients } \\
\hline & Before & After & $P<$ & Before & After & $P<$ \\
\hline$S B P(m m H g)$ & $122 \pm 8.6$ & $127 \pm 23.0$ & $n s$ & $163 \pm 15.6$ & $153 \pm 15.9$ & 0.05 \\
\hline$D B P(m m H g)$ & $78 \pm 8.0$ & $85 \pm 8.6$ & 0.01 & $98 \pm 6.8$ & $100 \pm 7.6$ & $n s$ \\
\hline$M B P(m m H g)$ & $93 \pm 7.1$ & $99 \pm 12.1$ & 0.05 & $120 \pm 9.5$ & $117 \pm 9.9$ & $n s$ \\
\hline$C I\left(L / \min / m^{2}\right)$ & $4.29 \pm 1.811$ & $3.18 \pm 1.292$ & 0.01 & $4.69 \pm 1.381$ & $3.04 \pm 1.244$ & 0.001 \\
\hline$H R$ (beats/min) & $70 \pm 7.5$ & $62 \pm 7.0$ & 0.001 & $74 \pm 14.1$ & $65 \pm 9.4$ & 0.001 \\
\hline$S I\left(\mathrm{ml} /\right.$ beat $\left./ \mathrm{m}^{2}\right)$ & $61 \pm 23.0$ & $52 \pm 20.6$ & $n s$ & $64 \pm 16.3$ & $47 \pm 17.2$ & 0.01 \\
\hline TPRI (dyne.sec. $\left.\mathrm{cm}^{-5} \cdot \mathrm{m}^{2}\right)$ & $1976 \pm 711.9$ & $2971 \pm 1516.8$ & 0.05 & $2251 \pm 821.7$ & $3507 \pm 1228.2$ & 0.001 \\
\hline$L V W I\left(\mathrm{~kg} \cdot \mathrm{m} / \mathrm{min} / \mathrm{m}^{2}\right)$ & $5.5 \pm 2.61$ & $4.3 \pm 1.77$ & 0.05 & $7.6 \pm 2.20$ & $4.8 \pm 1.98$ & 0.001 \\
\hline
\end{tabular}

The cardiac output was determined before and $7 \mathrm{~min}$ after intravenously propranolol infusion of $1 \mathrm{mg} / \mathrm{min}$ for $5 \mathrm{~min}$. The results represent the means \pm standard deviation of the mean.

Abbreviations are the same as in Table II.

TABLE $V$ THE DIFFERENCES BETWEEN THE EFFECTS OF PROPRANOLOL ON THE HEMODYNAMICS IN NORMOTENSIVE SUBJECTS AND HYPERTENSIVE PATIENTS

\begin{tabular}{|c|c|c|c|}
\hline & Normotensive subjects & Hypertensive patients & $P<$ \\
\hline$\Delta S B P(m m H g)$ & +6 & -10 & 0.05 \\
\hline$\triangle D B P(m m H g)$ & +7 & +1 & 0.05 \\
\hline$\triangle M B P(m m H g)$ & +6 & -3 & 0.05 \\
\hline$\Delta C I\left(L / \mathrm{min} / \mathrm{m}^{2}\right)$ & -1.12 & -1.66 & $n s$ \\
\hline$\Delta H R$ (beats $/ \mathrm{min})$ & -8 & -9 & $n s$ \\
\hline$\Delta S I\left(\mathrm{ml} / \mathrm{beat} / \mathrm{m}^{2}\right)$ & -9 & -17 & $n s$ \\
\hline$\triangle T P R I\left(\right.$ dyne.sec. $\left.\mathrm{cm}^{-5} \cdot \mathrm{m}^{2}\right)$ & +995 & +1257 & $n s$ \\
\hline$\Delta L V W I\left(\mathrm{~kg} \cdot \mathrm{m} / \mathrm{min} / \mathrm{m}^{2}\right)$ & -1.23 & -2.80 & 0.05 \\
\hline
\end{tabular}

Abbreviations: $\Delta=$ mean difference between the values before and after the administration of propranolol. Other abbreviation as in Table II.

$(p<0.001)$ in hypertensive group. The significant difference in these increases between the two groups was not demonstrated.

Response to Propranolol Infusion ( Table IV to V, Fig .2 ).

As shown in Fig.2, there was a variable response of blood pressure after the intravenous administration of $5 \mathrm{mg}$ of propranolol. Interestingly, three normotensive subjects showed considerable rises in blood pressure due to marked increases in TPRI. The blood pressure response in normotensive group, therefore, differed significantly from that in hypertensive group. Whereas in normotensive group the mean systolic pressure showed a slight nonsignificant rise, in hypertensive group it showed a significant fall from 163 to $153 \mathrm{mmHg}(\mathrm{p}<0.05)$. Although the rise in diastolic pressure was not significant in hypertensive group, there was a significant rise from 78 to $85 \mathrm{mmHg}$ in normotensive group $(\mathrm{p}<0.01)$. In normotensive group the mean blood pressure rose slightly but significantly $(\mathrm{p}<0.05)$. How- 

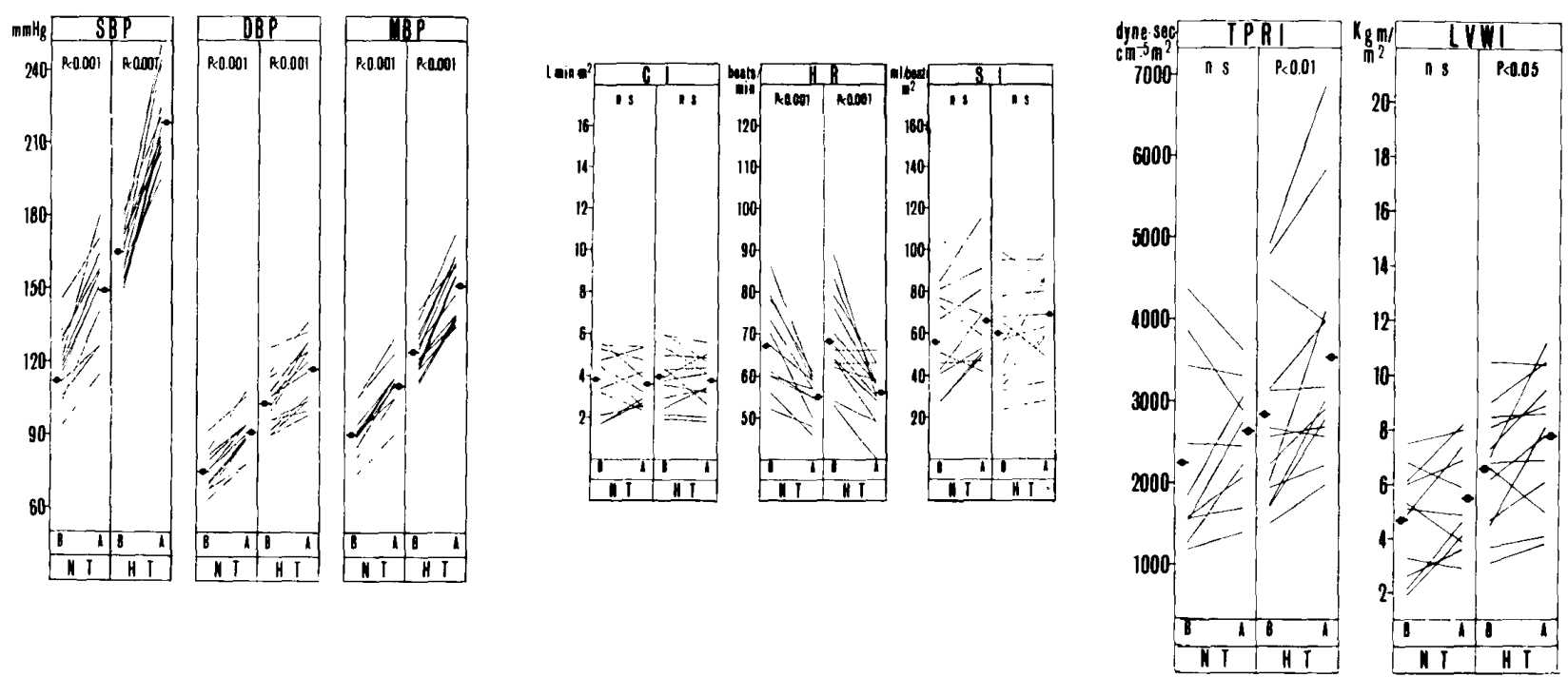

Fig.3. Effect of noradrenaline infusion on the hemodynamics in normotensive subjects (NT) and hypertensive patients (HT).

$\mathrm{B}=$ before and $\mathrm{A}=$ after noradrenaline. Other abbreviations as in Table II.

ever, in hypertensive group the mean blood pressure reduced by $3 \mathrm{mmHg}$ on the average. The average cardiac index decreased from 4.29 to $3.18 \mathrm{~L} / \mathrm{min} / \mathrm{m}^{2} \quad(\mathrm{p}<0.01)$ in normotensive group and from 4.69 to $3.04 \mathrm{~L} / \mathrm{min} / \mathrm{m}^{2}$ $(p<0.001)$ in hypertensive group. The average heart rate decreased from 70 to 62 beats $/ \mathrm{min}$. $(p<0.001)$ in normotensive group and from 74 to 65 beats/min $(p<0.001)$ in hypertensive group. The mean stroke index decreased in both groups, but this change was significant only for hypertensive group, in which the average stroke index decreased from 64 to $47 \mathrm{ml} /$ beat $/ \mathrm{m}^{2}(p<0.01)$. However, there were no apparent difference in response of cardiac index, heart rate and stroke index between the two groups. Average TPRI increased from 1976 to 2971 dyne $\cdot \mathrm{sec} \cdot \mathrm{cm}^{-5} \cdot \mathrm{m}^{2}$ $(\mathrm{p}<0.05)$ in normotensive group and from 2251 to 3507 dyne $\cdot \mathrm{sec} \cdot \mathrm{cm}^{-5} \cdot \mathrm{m}^{2} \quad(\mathrm{p}<0.001)$ in hypertensive group, the difference being not significant. Average reduction in LVWI was $1.23 \mathrm{Kg} \cdot \mathrm{m} / \mathrm{min} / \mathrm{m}^{2}(\mathrm{p}<0.05)$ in normotensive group and $2.80 \mathrm{Kg} \cdot \mathrm{m} / \mathrm{min} / \mathrm{m}^{2}(\mathrm{p}<0.001)$ in hypertensive group; the latter was significantly greater than the former $(p<0.05)$.

Response to Noradrenaline Infusion ( Table VI to VII, Fig .3 ).

The intravenous infusion of noradrenaline at a. rate of $15 \mu \mathrm{g} / \mathrm{min}$ resulted in a highly significant rise in blood pressure in both groups. The significant difference in the pressor responses between the two groups was not observed except for systolic pressure. The average systolic pressure rose from 118 to $149 \mathrm{mmHg}$ in normotensive group andfrom 165 to $218 \mathrm{mmHg}$ in hypertensive group ; this response was significantly greater in hypertensive group than in normotensive group $(p<0.001)$. The behaviour of the mean values of cardiac index, heart rate and stroke index was similar in both groups. Cardiac index was not affected in both groups, while the average heart rate decreased by 12 beats/min $(\mathrm{p}<0.001)$ in normotensive group and by 13 beats/min $(p<0.001)$ in hypertensive group, the difference being not significant. On the other hand, stroke index had a tendency to increase; the mean value was $10 \mathrm{ml} / \mathrm{beat} / \mathrm{m}^{2}$ in normotensive group and $9 \mathrm{ml} /$ beat $/ \mathrm{m}^{2}$ in hypertensive group, which were not significant. The mean TPRI and LVWI increased in both groups, but these changes were significantly only for hypertensive group ( $p<0.01$ and $p<0.05$, respectively). Statistically, however, these increases were not significantly greater in hypertensive group than in normotensive group. Average TPRI increased from 2251 to 2644 dyne $\cdot \mathrm{sec} \cdot \mathrm{cm}^{-5} \cdot \mathrm{m}^{2}$ in normotensive group and from 2853 to 3546 dyne.sec. $\mathrm{cm}^{-5} \cdot \mathrm{m}^{2}$ in hypertensive group. The average increase in LVWI was $0.8 \mathrm{Kg} \cdot \mathrm{m} / \mathrm{min} / \mathrm{m}^{2}$ in normotensive group and $1.1 \mathrm{Kg} \cdot \mathrm{m} / \mathrm{min} / \mathrm{m}^{2}$ in hypertensive group.

Response to Phentolamine Infusion (Table VIII 
TABLE VI THE EFFECT OF THE ADMINISTRATION OF NORADRENALINE ON THE HEMODYNAMICS IN NORMOTENSIVE SUBJECTS AND HYPERTENSIVE PATIENTS

\begin{tabular}{|c|c|c|c|c|c|c|}
\hline & \multicolumn{2}{|c|}{ Normotensive subjects } & \multicolumn{4}{|c|}{ Hypertensive patients } \\
\hline & Before & After & $P<$ & Before & After & $P<$ \\
\hline$S B P(m m H g)$ & $118 \pm 14.2$ & $149 \pm 20.3$ & 0.001 & $165 \pm 11.0$ & $218 \pm 17.7$ & 0.001 \\
\hline$D B P(m m H g)$ & $75 \pm 8.4$ & $91 \pm 9.5$ & 0.001 & $103 \pm 10.9$ & $117 \pm 13.1$ & 0.001 \\
\hline$M B P(m m H g)$ & $90 \pm 9.5$ & $111 \pm 11.9$ & 0.001 & $124 \pm 9.1$ & $151 \pm 12.8$ & 0.001 \\
\hline$C I\left(L / \mathrm{min} / \mathrm{m}^{2}\right)$ & $3.81 \pm 1.487$ & $3.62 \pm 1.146$ & ns & $3.96 \pm 1.354$ & $3.79 \pm 1.158$ & $n s$ \\
\hline$H R$ (beats/min) & $67 \pm 10.7$ & $55 \pm 5.1$ & 0.001 & $68 \pm 10.7$ & $56 \pm 7.0$ & 0.001 \\
\hline$S I\left(m l /\right.$ beat $\left./ m^{2}\right)$ & $56 \pm 21.0$ & $66 \pm 22.2$ & $n s$ & $60 \pm 23.6$ & $69 \pm 22.1$ & $n s$ \\
\hline TPRI (dyne.sec. $\left.\mathrm{cm}^{-5} \cdot \mathrm{m}^{2}\right) 2$ & $2251 \pm 1119.5$ & $2644 \pm 742.5$ & $n s$ & $2853 \pm 1191.3$ & $3546 \pm 1413.7$ & 0.01 \\
\hline$L V W I\left(\mathrm{~kg} \cdot \mathrm{m} / \mathrm{min} / \mathrm{m}^{2}\right)$ & $4.7 \pm 1.93$ & $5.5 \pm 1.88$ & $n s$ & $6.6 \pm 2.17$ & $7.8 \pm 2.44$ & 0.05 \\
\hline
\end{tabular}

The cardiac output was determined before and 5 min after intravenously noradrenaline infusion of $15 \mu \mathrm{g} / \mathrm{min}$ for $8 \mathrm{~min}$. The results represent the means \pm standard deviation of the mean.

Abbreviations are the same as in Table II.

TABLE VII THE DIFFERENCES BETWEEN THE EFFECTS OF NORADRENALINE ON THE HEMODYNAMICS IN NORMOTENSIVE SUBJECTS AND HYPERTENSIVE PATIENTS

\begin{tabular}{|c|c|c|c|}
\hline & Normotensive subjects & Hypertensive patients & $P<$ \\
\hline$\triangle S B P(m m H g)$ & +31 & +53 & 0.001 \\
\hline$\triangle D B P(m m H g)$ & +16 & +14 & ns \\
\hline$\triangle M B P(m m H g)$ & +21 & +27 & $n s$ \\
\hline$\Delta C I\left(L / \mathrm{min} / \mathrm{m}^{2}\right)$ & -0.20 & -0.17 & $n s$ \\
\hline$\Delta H R($ beats $/ \min )$ & -12 & -13 & $n s$ \\
\hline$\Delta S I\left(\mathrm{ml} /\right.$ beat $\left./ \mathrm{m}^{2}\right)$ & +10 & +9 & $n s$ \\
\hline$\Delta T P R I\left(\right.$ dyne.sec. $\left.\mathrm{cm}^{-5} \cdot \mathrm{m}^{2}\right)$ & +393 & +693 & $n s$ \\
\hline$\Delta L V W I\left(\mathrm{~kg} \cdot \mathrm{m} / \mathrm{min} / \mathrm{m}^{2}\right)$ & +0.8 & +1.1 & ns \\
\hline
\end{tabular}

Abbreviations: $\Delta=$ mean difference between the values before and after the administration of noradrenaline. Other abbreviations as in Table II.

to IX, Fig. 4).

In both groups the constant intravenous infusion of phentolamine at a rate of $2 \mathrm{mg} / \mathrm{min}$ produced a fall of blood pressure, which was significant with the exception of the reduction of systolic pressure in normotensive group. Phentolamine failed to reduce systolic pressure in normotensive group, while it produced a significant fall in systolic pressure in hypertensive group, in which the average value fell from 171 to $154 \mathrm{mmHg}(\mathrm{p}<0.001)$. Although diastolic and mean blood pressure fell significantly in both groups, these reductions were also significantly greater in hypertensive group than in normotensive group. There was no change in cardiac index in hypertensive group, and in normotensive group there was a tendency for cardiac index to increase. The average increase in cardiac index was $1.49 \mathrm{~L} / \mathrm{min} / \mathrm{m}^{2}$ in normotensive group and only $0.03 \mathrm{~L} / \mathrm{min} / \mathrm{m}^{2}$ in hypertensive group, both of which were not significant. The average heart rate increased by 11 beats/min $(p<0.001)$ in 

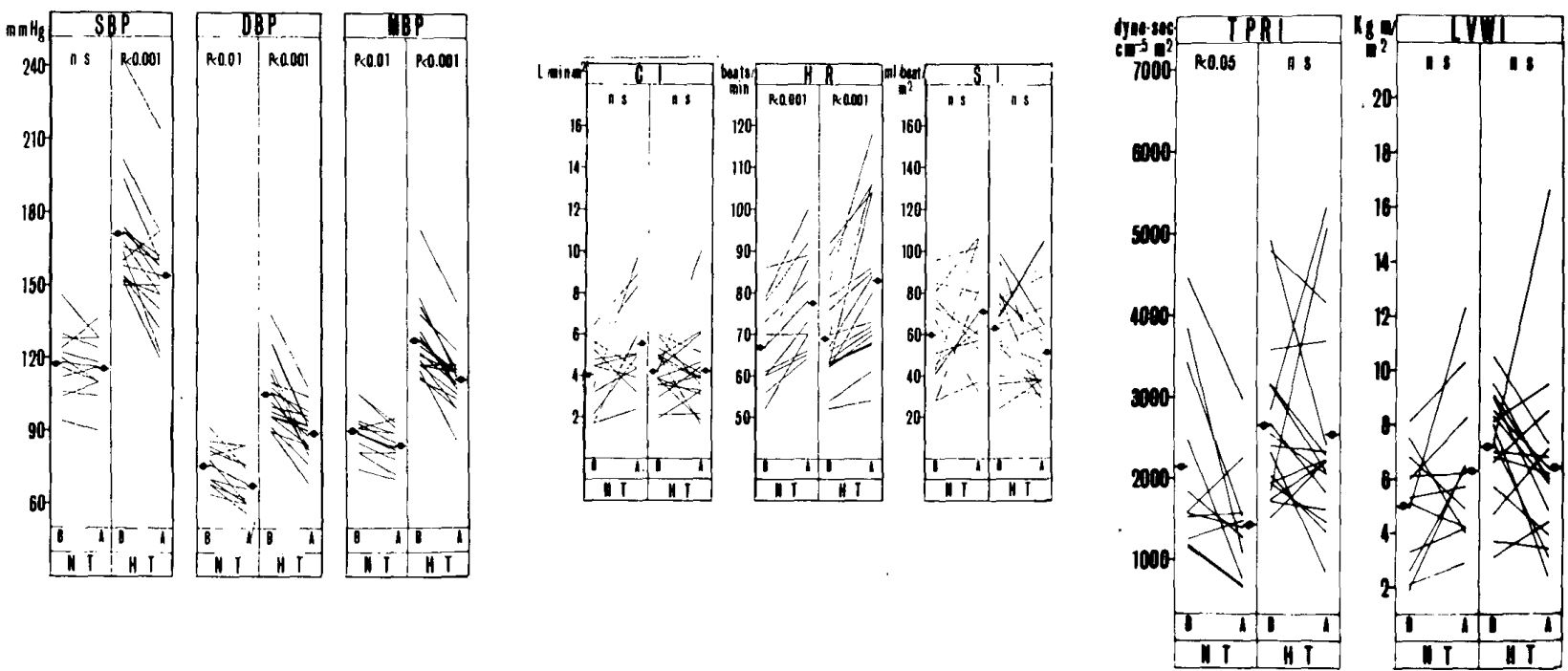

Fig.4. Effect of phentolamine infusion on the hemodynamics in normotensive subjects (NT) and hypertensive patients (HT).

$\mathrm{B}=$ before and $\mathrm{A}=$ after phentolamine.

Other abbreviations as in Table II.

TABLE VIII THE EFFECT OF THE ADMINISTRATION OF PHENTOLAMINE ON THE HEMODYNAMICS IN NORMOTENSIVE SUBJECTS AND HYPERTENSIVE PATIENTS

\begin{tabular}{|c|c|c|c|c|c|c|}
\hline & \multicolumn{2}{|c|}{ Normotensive subjects } & \multicolumn{4}{|c|}{ Hypertensive patients } \\
\hline & Before & After & $P<$ & Before & After & $P<$ \\
\hline$S B P(m m H g)$ & $118 \pm 13.6$ & $116 \pm 12.4$ & $n s$ & $171 \pm 23.3$ & $154 \pm 21.5$ & 0.001 \\
\hline$D B P(m m H g)$ & $76 \pm 8.1$ & $68 \pm 8.7$ & 0.01 & $105 \pm 13.0$ & $89 \pm 10.0$ & 0.001 \\
\hline$M B P(m m H g)$ & $90 \pm 9.2$ & $84 \pm 7.9$ & 0.01 & $127 \pm 15.5$ & $111 \pm 12.0$ & 0.001 \\
\hline$C I\left(L / \min / m^{2}\right)$ & $4.03 \pm 1.620$ & $5.52 \pm 2.302$ & $n s$ & $4.20 \pm 1.165$ & $4.24 \pm 2.102$ & $n s$ \\
\hline$H R$ (beats/min) & $67 \pm 10.2$ & $78 \pm 12.0$ & 0.001 & $69 \pm 11.2$ & $83 \pm 18.5$ & 0.001 \\
\hline$S I\left(m l / b e a t / m^{2}\right)$ & $60 \pm 23.0$ & $71 \pm 25.3$ & $n s$ & $63 \pm 21.5$ & $51 \pm 22.0$ & $n s$ \\
\hline$T P R I\left(\right.$ dyne.sec. $\left.\mathrm{cm}^{-5} \cdot \mathrm{m}^{2}\right)$ & $2159 \pm 1111.0$ & $1429 \pm 651.1$ & 0.05 & $2661 \pm 1008.7$ & $2547 \pm 1267.4$ & $n s$ \\
\hline$L V W I\left(\mathrm{~kg} \cdot \mathrm{m} / \mathrm{min} / \mathrm{m}^{2}\right)$ & $5.0 \pm 2.09$ & $6.3 \pm 2.76$ & $n s$ & $7.2 \pm 2.02$ & $6.4 \pm 3.25$ & $n s$ \\
\hline
\end{tabular}

The cardiac output was determined before and $5 \mathrm{~min}$ after intravenously phentolamine infusion of $2 \mathrm{mg} / \mathrm{min}$ for $8 \mathrm{~min}$. The results represent the means \pm standard deviation of the mean.

Abbreviations are the same as in Table II.

normotensive group and by 14 beats/min $(p<0.001)$ in hypertensive group, the difference being not significant. The administration of phentolamine produced a variable effect on stroke index, the normotensive group raising it by a mean of $11 \mathrm{ml} / \mathrm{min} / \mathrm{m}^{2}$ and the hypertensive group reducing it by a mean of $12 \mathrm{ml} / \mathrm{min} /$ $\mathrm{m}^{2}$. The difference in these responses between the two groups was significant $(p<0.05)$. The mean TPRI decreased in both groups, but this change was significant only for normotensive group $(\mathrm{p}<0.05)$. Average TPRI decreased from 2159 to 1429 dyne $\cdot \mathrm{sec} \cdot \mathrm{cm}^{-5} \cdot \mathrm{m}^{2}$ in normotensive group and from 2661 to 2547 dyne $\cdot \mathrm{sec} \cdot \mathrm{cm}^{-5}$. $\mathrm{m}^{2}$ in hypertensive group; this reduction was significantly greater in normotensive group than in hypertensive group $(\mathrm{p}<0.05)$.

Whereas in normotensive group there was a 
TABLE IX THE DIFFERENCES BETWEEN THE EFFECTS OF PHENTOLAMINE ON THE HEMODYNAMICS IN NORMOTENSIVE SUBJECTS AND HYPERTENSIVE PATIENTS

\begin{tabular}{|c|c|c|c|}
\hline & \multicolumn{2}{|c|}{ Normotensive subjects Hypertensive patients } & \multirow{2}{*}{$\begin{array}{c}P< \\
0.01\end{array}$} \\
\hline$\triangle S B P(m m H g)$ & -3 & -17 & \\
\hline$\triangle D B P(m m H g)$ & -8 & -16 & 0.05 \\
\hline$\triangle M B P(m m H g)$ & -6 & -17 & 0.01 \\
\hline$\Delta C I\left(L / \min / m^{2}\right)$ & +1.49 & +0.03 & ns \\
\hline$\Delta H R$ (beats $/ \mathrm{min})$ & +11 & +14 & $n s$ \\
\hline$\Delta S I\left(m l / b e a t / m^{2}\right)$ & +11 & -12 & 0.05 \\
\hline$\Delta T P R I\left(\right.$ dyne.sec, $\left.\mathrm{cm}^{-5} \cdot \mathrm{m}^{2}\right)$ & -730 & -114 & 0.05 \\
\hline$\Delta L V W I\left(\mathrm{~kg} \cdot \mathrm{m} / \mathrm{min} / \mathrm{m}^{2}\right)$ & +1.3 & -0.9 & 0.05 \\
\hline
\end{tabular}

Abbreviations: $\Delta=$ mean difference between the values before and after the administration of phentolamine. Other abbreviations as in Table II.

\begin{tabular}{|c|c|c|c|c|c|c|c|c|}
\hline $\begin{array}{l}\text { Infusion } \\
\text { Parameter }\end{array}$ & Isopro & renol & Propr & 0101 & Morad & raline & Phento & lamine \\
\hline$S B P$ & & & $\triangle$ & $=$ & & & $\infty$ & $\Rightarrow$ \\
\hline$D B P$ & 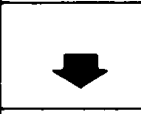 & - & - & $\Delta$ & - & - & - & 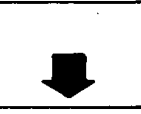 \\
\hline M B P & $\diamond$ & $=$ & - & $\nabla$ & - & - & $=$ & $\nabla$ \\
\hline CI & 1 & 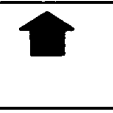 & $=$ & - & $\varnothing$ & 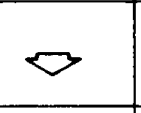 & $\Delta$ & $\Delta$ \\
\hline H R & - & - & $=$ & $\Rightarrow$ & $=$ & 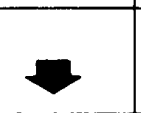 & - & - \\
\hline S I & - & $\Delta$ & $\theta$ & $=$ & $\Delta$ & $\Delta$ & $\Delta$ & $\infty$ \\
\hline TPRI & 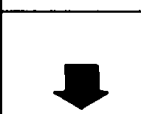 & 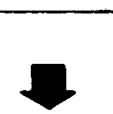 & - & - & $\Delta$ & - & $\Rightarrow$ & $\infty$ \\
\hline LVWI & - & 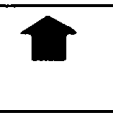 & $n$ & e & $\Delta$ & - & $\Delta$ & $\infty$ \\
\hline
\end{tabular}

Fig.5. Summary of cardiovascular responses to the intravenous infusion of $\alpha$-stimulant, $\alpha$-blocker, $\beta$-stimulant and $\beta$-blocker.

$\checkmark=$ tendency to increase of decrease, but not significant.

$\mathcal{L}=$ significant increase or decrease.

$*, * *, * * *=\mathrm{P}$ value of $<0.05,<0.01$, and $<0.001$ for the differences between the effects of each drug on the hemodynamics in normotensive subjects (NT) and hypertensive patients (HT).

Other abbreviations as in Table II. 
tendency for LVWI to increase, in hypertensive group there was a tendency for LVWI to decrease. Although these changes were not significant, the difference in these responses between the two groups was statistically significant $(\mathrm{p}<0.05)$.

\section{Discussion}

As shown in Fig. 5 there were little significant differences between normotensive and hypertensive groups with respect to cardiovascular response to the drug infusion, but there were considerably significant differences in the blood pressure responses to these drugs between both groups.

Two reasons may be listed for this discrepancy. First, there existed a technical failure in the determination of cardiac output. Secondly, there occurred a homeostatic reflex which would modify the response of blood pressure to the drugs.

In normotensive subjects isoproterenol produced significant increases in systolic pressure, cardiac index, heart rate, stroke index and LVWI, while it produced decreases in diastolic pressure and TPRI. The mean blood pressure was not significantly affected. These hemodynamic responses to this drug in normotensive subjects were similar to those described by previous investigators 9,10 There have been very few reports on the hemodynamic response to the intravenous infusion of isoproterenol in essential hypertensive patients.

Frohlich et al. recently reported that the cardiac response to isoproterenol infusion in patients with labile hypertension was not different from that in patients having mild essential hypertension, and that the only significant difference was a rise in arterial $\mathrm{dP} / \mathrm{dt}$ and left ventricular ejection rate at the higher concentrations of isoproterenol infused, which were greater in the former patients than in the latter. However, they did not compare the hemodynamic response to isoproterenol infusion in hypertensive patients with that in normotensive subjects. In the present study, some hypertensive patients showed a fall in blood pressure which was due to a marked reduction in TPRI induced by isoproterenol. Although significant differences in the cardiovascular response between normotensive and hypertensive group was not observed, the increase in stroke index induced by isoproterenol tended to be smaller in hypertensive group as compared to normotensive group.
The prolonged oral administration of the beta adrenergic blocking drugs, such as pronethalol and propranolol have been reported to have a hypotensive effect in hypertension.1-15 However, several workers observed that the hypotensive effect of the drugs is modest or insignificant ${ }^{16-18}$ Prichard and Gillam ${ }^{15}$ postulated that the baroreceptors may be gradually conditioned by damping of pressor responses to regulate the blood pressure at a lower level so that later the resting blood pressure also falls. On the other hand, it has been observed that beta receptor blocking drugs have no hypotensive action when given intravenously $11,12,20$ In the present study, three normotensive subjects showed a marked rise in blood pressure due to marked increase in TPRI. The pressor action of propranolol has been observed in dogs, $21-23$ rats 24 and patients with pheochromocytoma 25 or neurocirculatory asthenia ${ }^{26}$ Whether this pressor action is due to the increased reflex sympathoadrenal activity, ${ }^{21}$ the release of catecholamines from the adrenal medulla ${ }^{22}$ the blockade of the strong beta adrenergic receptor tone in the vessels of skeletal muscle, ${ }^{24}$ or the combination of some causes ${ }^{23}$ is not known. From other clinical studies, ${ }^{27-30}$ it is known that beta receptor blocking drugs can abolish the vasodialatation in the muscle blood vessels induced by catecholamines. It was also reported that the muscle blood flow was greater in essential hypertension and that the decrease in cardiac output after propranolol was prominent in cases of high cardiac output 14,32,33 Exept for 3 cases which showed anomalous responses, the increase in TPRI was more striking in hypertensive group than in normotensive group, as shown in Fig. 2. Although the difference in the fall in cardiac index was not significant between normotensive and hypertensive groups, its reduction was prominent in hypertensive group on the average. In addition, the fall in cardiac index was dependent on the reduction of heart rate and stroke index in hypertensive group, whereas the fall was mainly dependent on the reduction of heart rate in normotensive group. Hemodynamic changes induced by propranolol may be explained on the basis of the following assumption. Propranolol has a direct effect on the peripheral vascular beds, particularly in the muscles, as well as on the heart. Accordingly, the fall in cardiac output is not only due to direct depressant action of propranolol on the heart, but also due to compensation for its direct vasoconstriction. It is 
reasonable to conclude that propranolol produced a greater vasoconstriction in hypertensive patients with low vascular resistance in the muscles, and that the cardiac index decreased more strongly, because of reductions in heart rate and in stroke index, in hypertensive patients. On the contrary, Ulrych et al. ${ }^{20}$ observed that propranolol produced a greater inhibition of chronotropic activity in hypertensive patients, and of stroke volume in normotensive individuals, suggesting that diastolic hypertension may be associated with increased chronotropic beta adrenergic activity. However, the overall results for the effects of $\beta$-adrenergic stimulant and $\beta$-adrenergic blockade showed that there was no increased beta adrenergic activity in essential hypertension. Further work is needed to get information concerning marked pressor response to propranolol.

Vascular reactivity in hypertension has been reported as being increased ${ }^{34-41}$ or not different from normal response ${ }^{42-44}$ Since different methods have been used under various conditions in this type of investigation, controversy has developed with reference to the interpretation of the experimental results. Increased vascular reactivity was elicited by prior ganglion blockade $35,36,41,46$ and was observed in the normotensive children of patients with essential hypertension $37,38,40$ It was found that ganglion blocking agents lowered blood pressure mainly through a reduction in cardiac output 47,48 In other study, 49 it was shown that the degree of the fall in blood pressure after ganglion blockade with hexamethonium was dependent on the initial level and that hexamethonium changed the relationship between the pressor responses to noradrenaline of renal hypertensive and control rats. It was also found that hypertensive patients had a hightened vascular response not only to noradrenaline but also to other vasoactive substances such as angiotensin and 5-hydroxytryptamine $3^{36}$ The question has been raised as to whether hypertensive patients differ in the degree of effect of sympathetic blockade from normotensive subjects, and whether normotensive children of hypertensive patients have increased cerebral excitability. On the other hand, it was reported that increased vascular reactivity might result from structural changes in the arterial wall $46,50,51$ In addition to the possibility that waterlogging and hypertrophy by increasing the wall thickness of arterioles could produce apparent hyper-responsiveness without actual hyper-responsiveness, ${ }^{52,53}$ Redleaf and Tobian ${ }^{50}$ pointed out that for a similar shortening of the muscle in the arteriolar wall, a greater increase in resistance will occur in the already constricted vessel than in the relaxed vessel. These results cast some doubt on the view that hyper-responsiveness of blood vessels is a causal factor in hypertension. In the present study, the effect of noradrenaline on the heart was similar in both normotensive and hypertensive groups. Noradrenaline has a little beta adrenergic activity in addition to a potent alpha adrenergic activity, ${ }^{2}$ but the direct action of noradrenaline is opposed by reflex vagal inhibition due to blood pressure elevation, resulting in the reduction of heart rate ${ }^{54}$ Although preliminary ganglion blockade was not given in the present study, it was shown that the rise in systolic pressure was significantly greater and that the increase in TPRI tended to be greater in hypertensive group than in normotensive group.

These findings suggested that the hyper-responsiveness to noradrenaline in patients with essential hypertension might be not only due to arteriolar vasoconstriction but also due to aortic sclerosis. If arteriolar vasoconstriction can occur more strongly in hypertensive patients, it could result in greater increases in diastolic pressure and in TPRI than in normotensive group. Moreover, if the alpha adrenergic receptor of hypertensive blood vessels is more sensitive to noradrenaline than that of normotensive blood vessels, the cardiodynamic changes modified by reflex adjustments of baroreceptors may be greater in hypertensive group. From these considerations and the results obtained during phentolamine infusion, which will be discussed below, the increased vascular reactivity is thought a nonspecific manifestation which resulted from the structural narrowing of blood vessels. The vascular reactivity in essential hypertension has been extensively studied with the use of noradrenaline, but only a few studies have been done with the use of $\alpha$-receptor blockade, e.g., phentolamine. Kikuiri, ${ }^{55}$ a coworker of Miyahara et $a l_{0}^{40,41}$ who claimed the increased vascular reactivity to noradrenaline in essential hypertension, reported that the fall in mean blood pres. sure, total and digital vascular resistance and the increase in digital blood flow were significantly greater in hypertensive patients. However, the detail method was not described in his report. On the other hand, phentolamine is known to have several pharmacological actions such as follows: ${ }^{56-59}$ (1) $\alpha$-adrenergic blocking action, (2) 
mild sympatholitic action, (3) antagonistic action to circulating catecholamines, (4) direct relaxing effect on the vascular smooth muscle including the larger arteries and veins, (5) $\beta$-adrenergic stimulating action. It is, therefore, a little question as to whether or not phentolamine is a suitable agent for the study of the behavior of alpha adrenergic receptor. With regard to the effects of acute and constant intravenous injection of phentolamine on the hemodynamics, Taylor et al. ${ }^{58,59}$ reported that phentolamine produced a decrease in TPRI which resulted in a fall in mean blood pressure in spite of the increase in heart rate and the small increase in cardiac index. However, they did not observe any significant difference in percentage changes of hemodynamic parameters between normal subjects and hypertensive patients except for the differences in pluse pressure, attainment of the maximum fall in TPRI and pattern of return of TPRI toward preinfusion control values. Because of the paucity of materials they made no mention of the statistical differences in the hemodynamic responses between normal subjects and hypertensive patients. In the present study, the depressor effects of phentolamine was significantly greater in hypertensive group. In spite of some individual variations in the responses of cardiac index, stroke index, TPRI and LVWI during the infusion of phentolamine, the average changes showed the following tendency. Contrary to our expectation, the reduction in TPRI was significantly greater in normotensive group, in which its reduction was followed by the appreciable increase in cardiac index and stroke index in addition to significant increase in heart rate, resulting in the less prominent fall in blood pressure. In hypertensive group, phentolamine produced an appreciable reduction in stroke index in spite of significant increase in heart rate. Although the fall in blood pressure was associated with reduction in TPRI in most cases, there were some exceptions which were more frequently observed in hypertensive patients. Following explanations would be proposed for the different hemodynamic responsiveness between the two groups. Presumably the arteriolar vessels in hypertensive patients could not so fully dilate, because of the organic changes of blood vessels, as those of normotensive subjects. In addition, it was also thought that normotensive heart compensated considerably fro the reduction in TPRI with the increase in stroke index, and that hypertensive heart had not a little myocardial ischemic change, and, thereby, could not fully compensate for the reduction in TPRI, or stroke index needed not increase because of the decrease in the pressure work of the heart. At least, it seems unlikely from our data that the increased vascular reactivity exists in essential hypertension. Many functions of the cardiovascular system have been said to be regulated by local autoregulation, moderate reflex and other mechanisms. It is also known that the homeostatic regulatory mechanisms are reset to maintain a high level of blood pressure in essential hypertension 60 The regulatory system should behave so that if the magnitude of blood pressure is displaced from the set value, the system will respond so as to return the magnitude toward its set value. Further study along this line is necessary.

\section{CONCLUSION}

1. Hemodynamic responses to the intravenous infusion of isoproterenol, propranolol, noradrenaline and phentolamine were examined in normotensive subjects and hypertensive patients.

2. Neither increased beta adrenergic activity nor alpha adrenergic activity was observed in essential hypertension.

3. Three of 14 normotensive subjects showed a marked pressor response to propranolol. Such a case was not observed in hypertensive patients. 4. Propranolol tended to produce a greater vasoconstriction in hypertensive patients, suggesting the increased muscle blood flow in essential hypertension.

5. Hyper-responsiveness to noradrenaline in hypertension was demonstrated in the case of systolic blood pressure and TPRI, suggesting that the increased reactivity is not only due to arteriolar vasoconstriction but also due to sclerosis of the larger arteries.

6. Phentolamine produced greater depressor responses in hypertensive patients, but the reduction in TPRI was not prominent in hypertensive patients as compared to normotensive subjects.

\section{Acknowledgement}

The author is grateful to Prof. Mototaka Murakami for his valuable suggestions and he wishes to express his thanks to Dr. Eiji Murakami, who has followed the course of this work throughout. Thanks are also due to Dr. N. Takekoshi, Dr. Y. Hiramaru, Dr. T. Onoe, Dr. T. Kin, Dr. N. Takeuchi, Dr. T. Funatsu, Dr. S. Ishise, Dr. S. Hara, Dr. J. Mifune, and Dr. S. Matsui for their technical advice. 


\section{REFERENCES}

1. DALE, H. H.: On some physiological actions of ergot. J. Physiol. 34: 163, 1906.

2. AHLQUIST, R. P.: A study of the adrenotropic receptors. Am. J. Physiol. 153: 586, 1948.

3. TSUCHIYA, M.: Hemodynamic studies on hypertension. (Part I) Hemodynamic characteristics in the resting supine position. Jap. Circul.J. (in press).

4. FROHLICH, E. D., DUSTAN, H. P., \& PAGE, I. H.: Hyperdynamic beta adrenergic circulatory state. Arch. Intern. Med. 117: 614, 1966

5. FROHLICH, E. D., TARAZI, R. C., \& DUSTAN, H. P.: Hyperdynamic $\beta$-adrenergic circulatory state: Increased $\beta$-receptor responsiveness. Arch. Intern. Med. 123: 1, 1969.

6. FROHLICH, E. D., DUSTAN, H. P., \& TARAZI, R. C.: Hyperdynamic beta-adrenergic circulatory state. Arch. Intern. Med. 126: 1068, 1970.

7. FROHLICH, E. D., KOZUL, V. J., TARAZI, R. C., \& DUSTAN, H. P.: Physiological comparison of labile and essential hypertension. Circul. Res. 26 and 27: (Suppl. I) I-55, 1970.

8. BLACK, J. W., CROWTHER, A. F., SHANKS, R, G., SMITH, L. H., \& DORNHORST, A. C.: A new adrenergic beta-receptor antagonist. Lancet 1 : $1080,1964$.

9. DODGE, H. T., LORD, J. D., \& SANDLER, H.: Cardiovascular effects of isoproterenol in normal subjects and subjects with congestive heart failure. Am. Heart J. 60: 94, 1960.

10. HARRIS, W. S., SCHOENFELD, C. D., BROOKS, R. H., \& WEISSLER, A. M.: Effect of beta adrenergic blockade on the hemodynamic responses to epinephrine in man. Am. J. Cardiol. 17: 484, 1966.

11. PRICHARD, B. N. C.: Hypotensive action of pronethalol. Brit. Med. J. 1: 1227, 1964.

12. PRICHARD, B. N.C. \& GILLAM, P. M. S.: The use of propranolol in the treatment of hypertension. Brit. Med.J. 2: 725, 1964.

13. SCHRÖDER, G. \& WERKÖ, L.: Nethalide, a beta adrenergic blocking agent. Clin. Pharmacol. Ther. 5: $159,1964$.

14. FROHLICH, E. D., TARAZI, R. C., DUSTAN, H. P., \& PAGE, I. H.: The paradox of beta-adrenergic blockade in hypertension. Circulation 37: 417, 1968.

15. PRICHARD, B. N. C. \& GILlAM, P. M. S.: Propranolol in hypertension. Am. J. Cardiol. 18: 387 , 1966.

16. RICHARDS, F. A.: Propranolol in hypertension. Am. J. Cardiol. 18: 384, 1966.

17. RICHARDSON, D. W., FREUND, J., GEAR, A. S., MAUCK, H. P., \& PRESTON, L. W.: Effect of propranolol on elevated arterial blood pressure. Circulation 37: 534, 1968.

18. WAAL, H. J.: Hypotensive action of propranolol, Clin. Pharmacol. Ther. 7: 588, 1966.

19. DORNHORST, A.C. \& ROBINSON, B. F.: Clinical pharmacology of a beta-adrenergic-blocking agent (Nethalide). Lancet 2: 314, 1962.

20. ULR YCH, M., FROHLICH, E. D., DUSTAN, H. P. \& PAGE, I. H.: Immediate hemodynamic effects of beta-adrenergic blockade with propranolol in normotensive and hypertensive man. Circulation 37: $411,1968$.
21. NAKANO, J. \& KUSAKARI, T.: Effect of propranolol on the peripheral circulation. Proc. Soc. Exp. Biol. Med. 120: 516, 1965.

22. KAYAALP, S. O. \& KIRAN, B. K.: Mechanism of a sympathomimetic action of propranolol in dog. Br. J. Pharmac. Chemother. 28: 15, 1966.

23. KAYAALP, S. O. \& TÜRKER, R. K.: Further observations on the pressor action of propranolol. Br. J. Pharmac. Chemother. 30: 668, 1967.

24. YAMAMOTO, J. \& SEKIYA, A.: On the pressor action of propranolol in the rat. Arch. Int. Pharmacodyn. 179: 372, 1969.

25. PATON, D. M.: Beta-receptor blockade in the diagnosis of phaeochromocytoma. Lancet 2: 1125 , 1964.

26. SCHWEITZER, P. M., PIVOŇKA, M., \& GREGOROVÁ, J.: The hemodynamic effects of beta-adrenergic blockade in patients with neurocirculatory asthenia. Cardiologia 52: 246, 1968.

27. LOWE, R. D. \& ROBINSON, B. F.: Effect of differential adrenergic blockade on response of forearm blood flow to infused catecholamines. Clin. Sci. 26: 81, 1964.

28. SCHOOP, W. \& SCHMIDTKE, I.: The effect of beta-adrenergic blocking substances on muscle blood flow in man. Angiologia 3: 141, 1965.

29. MAHON, W. A.: The peripheral vascular effects of beta adrenergic blocking agents in man. Angiologia 3: 304, 1966.

30. BRICK, I., GLOVER, W. E., HUTCHINSON, K. J., \& RODDIE, I.: Effects of propranolol on peripheral vessels in man. Am. J. Cardiol. 18: 329, 1966.

31. BROD, J., FENCL, V., HEJL, Z., JIRKA, J., \& ULRYCH, M.: General and regional haemodynamic pattern underlying essential hy pertension. Clin. Sci. 23: 339, 1962.

32. KURAMOTO, K., MURATA, K., YAZAKI, Y., IKEDA, M., \& NAKAO, K.: Hemodynamics in the juvenile hypertension with special reference to the response to propranolol. Jap. Circul. J. 32: 981, 1968.

33. BELLO, C. T., SEVY, R. W., HARAKAL, C., \& HILLYER, P. N.: Relationship between clinical severity of disease and hemodynamic patterns in essential hypertension. Am. J. Med. Sci. 253: 194, 1967.

34. GOLDENBERG, M., PINES, K. L., BALDWIN, E. F., GREENE, D. G., \& ROH, C. E.: The hemodynamic response of man to norepinephrine and epinephrine and its relation to the problem of hypertension. Am. J. Med. 5: 792, 1948.

35. MENDLOWITZ, M. \& NAFTCHI, N.: Work of digital vasoconstriction produced by infused norepinephrine in primary hypertension. J. Appl. Physiol. 13: 247, 1958.

36. DOYLE, A. E., FRASER, J. R. E., \& MARSHALL, R. L.: Reactivity of forearm vessels to vasoconstrictor substances in hypertensive and normotensive subjects. Clin. Sci. 18: 441, 1959.

37. DOYLE, A. E. \& FRASER, J. R. E.: Vascular reactivity in hypertension. Circulation Res. 9: 755 , 1961.

38. DOYLE, A. E. \& FRASER, J. R. E.: Essential hypertension and inheritance of vascular reactivity. Lancet 2: $509,1961$.

39. MENDLOWITZ, M., NAFTCHI, N. E., WOLF, R. 
L., \& GITLOW, S. E.: Vascular reactivity in the patient with essential hypertension and hypertension of renal origin. Am. J. Cardiol. 9: 680, 1962.

40. MIYAHARA, M., UEDA, T., \& IMURA, O.: Pressor response in essential hypertension: Blood pressure response to noradrenaline in the patients with essential hypertension. Jap. Heart J. 4: 417, 1963.

41. MIYAHARA, M.: Catecholamines and hemodynamic changes in hypertension. Jap. Circulation J. 30: $157,1966$.

42. JUDSON, W. E., EPSTEIN, F., \& WILKINS, R. W.: The comparative effects of small intravenous doses of 1-norepinephrine upon arterial pressure and pulse rate in normotensive subjects and in hypertensive patients before and after thoracolumbar sympathectomy. J. Clin. Invest. 29: 1414, 1950.

43. GOMBOS, E. A., HULET, W. H., BOPP, P., GOLDRING, W., BALWIN, D. S., \& CHASIS, H.: Reactivity of renal and systemic circulation to vasoconstrictor substances in normotensive and hypertensive subjects. J. Clin. Invest. 41: 203, 1962.

44. TAKEUCHI, J.: Etiology of juvenile hypertension. Jap. Circul.J. 30: 178, 1966.

45. MENDLOWITZ, M.: Vascular reactivity in essential and renal hypertension in man. Am. Heart J. 73: $121,1967$.

46. CONWAY, J.: Vascular reactivity in experimental hypertension measured after hexamethonium. Circulation 17: 807, 1958.

47. CRUMPTON, C. W., ROWE, G. G., O'BRIEN, G. S., \& MURPHY, Q. R., Jr.: The effect of hexamethonium bromide upon coronary flow, cardiac work and cardiac efficacy in normotensive and renal hypertensive dogs. Circul. Res. 2: 79, 1954.

48. CROSLEY, A. P., Jr., BROWN, J. F., TUCHMAN, H., CRUMPTON, C. W., HUSTON, J. H., \& ROWE, G. G.: The acute hemodynamic and metabolic response of hypertensive patients to pentolinium tartrate. Circulation 14: 584, 1956.

49. PHELAN, E. L.: Cardiovascular reactivity in rats with spontaneous inherited hypertension and constricted renal artery hypertension. Am. Heart J. 71 :
$50,1966$.

50. REDLEAF, P. D. \& TOBIAN, L.: The question of vascular hyper-responsiveness in hypertension. Circulation Res. 6: 185, 1958.

51. SIVERTSSON, R.: The hemodynamic importance of structural vascular changes in essential hypertension. Acta Physiol. Scand. suppl. 343: 1, 1970.

52. FOLKOW, B.: Structural, myogenic, humoral, and nervous factors controlling peripheral resistance. In Hypertensive Drugs, Harington, M.; Ed., London and New York, Pergamon Press, 1956, p.163.

53. TOBIAN, L. \& BINITON, J. T.: Tissue cations and water in arterial hypertension. Circulation 5: 754, 1952.

54. BARCROFT, H. \& KONZETT, H.: On the action of noradrenaline, adrenaline and isopropyl noradrenaline on the arterial blood pressure, heart rate and muscle blood flow in man. J. Physiol. 110: $194,1949$.

55. KIKUIRI, T.: Essential hypertension and catecholamine. Clinical Endocrinology 18: 293, 1970 (in Japanese).

56. GOULD, L., ZAHIR, M., \& ETTINGER, S.: Phentolamine and cardiovascular performance. Brit. Heart J. 31: 154, 1969.

57. GOULD, L.: Phentolamine. Am. Heart J. 78: 276, 1969.

58. TAYLOR, S. H., SUTHERLAND, G. R., MACKENZIE, G. J., STAUNTON, H. P., \& DONALD, K. W.: The circulatory effects of intravenous phentolamine in man. Circulation 31: 741, 1965.

59. TAYLOR, S. H., SUTHERLAND, G. R., MACKENZIE, G. J., STAUNTON, H. P., \& DONALD, K. W.: The circulatory effects of phentolamine in man with particular respect to changes in forearm blood flow. Clin. Sci. 28: 265, 1965.

60. FREIS, E. D.: Hemodynamics of hypertension. Physiol. Rev. 40: 27, 1960.

61. PETERSON, L. H.: Symposium on regulation of the cardiovascular system in health and disease: Introduction. Circulation 21: 739, 1960. 